Jan Mazur OSPPE

\title{
Inspiracje Centesimus annus dla polityki społecznej w ponowoczesnym społeczeństwie
}

Encyklikę społeczną Centesimus annus można dziś odczytać na nowo w oparciu o metodę zaproponowaną przez jej autora, Jana Pawła II. Upamiętniając w Centesimus annus encyklikę Leona XIII Rerum novarum, zasugerował on relekturę tego dokumentu w potrójnym aspekcie. Po pierwsze, zachęcił do spojrzenia wstecz, by raz jeszcze odczytać treść Rerum novarum. Po drugie, dokonał spojrzenia dokoła, wskazując na aktualnie występujące „rzeczy nowe”, pod wieloma względami różniące się od tych, które charakteryzowały koniec XIX wieku. I po trzecie, podjął trud spojrzenia w przyszłość, która, jakkolwiek pełna niewiadomych, może stanowić szansę dla twórczego zmysłu i wyobraźni inspirowanej chrześcijańską nadzieją ${ }^{1}$.

\section{Specyfika relektury Rerum novarum}

Odnośnie do spojrzenia wstecz ważne jest przypomnienie, że pod koniec XIX wieku nasilił się proces, który - wedle refleksji Jana Pawła II zawartej w Centesimus annus - wyraził się w całokształcie radykalnych przemian w dziedzinie politycznej, gospodarczej i społecznej, jak również na polu nauki i techniki. Dla dyskursu na temat polityki społecznej w ponowoczesnym społeczeństwie ważna jest konstatacja, że istotny czynnik owego procesu stanowiły „różnorakie wpływy dominujących ideologii”’. Papież wyjaśnił, że głównymi ideologiami w tym czasie były liberalizm ekonomiczny (popierający „całkowitą wolność ekonomiczną”)

\footnotetext{
1 CA 3 .

$2 \mathrm{CA} 4$.
} 
oraz szerzone wśród robotników najemnych koncepcje zwane „socjalistycznymi”'. Radykalne przemiany doprowadziły bowiem do podziału społeczeństwa na dwie skonfliktowane ze sobą klasy: właścicieli kapitału (kapitalistów) i pracowników najemnych (proletariat). Powstał konflikt między kapitałem a pracą, który Leon XIII w encyklice Rerum novarum nazwał „kwestią robotniczą"4.

Jan Paweł II, analizując kontekst społeczny Rerum novarum, napisał, że Leon xiII zabrał głos na mocy swego „urzędu apostolskiego” w obliczu „konfliktu, który przeciwstawiał człowieka człowiekowi, każąc im walczyć «niczym wilki», jednemu o przetrwanie, drugiemu o bogactwo"s. Na walkę o przetrwanie - jak wiadomo - skazany był proletariat, zaś o bogactwo walczyli właściciele kapitału. Autor Centesimus annus, nawiązując do kwestii społecznej końca XIX wieku, którą uznał za przejaw zła, postawił jednocześnie zasadnicze pytanie, kryjące w sobie syntetyczne spojrzenie na sprawy społeczne w ogólności. Spojrzawszy wstecz i jednocześnie dokoła, zaakcentował prawdę uniwersalną, niejako konkludując: „Skąd bowiem wywodzą się wszystkie przejawy zła, jakim encyklika Rerum novarum pragnie się przeciwstawić, jeśli nie $\mathrm{z}$ wolności, która w dziedzinie działalności gospodarczej i społecznej odrywa się od prawdy o człowieku?"6.

Nawiązanie do kontekstu społecznego i gospodarczego Rerum novarum kryje w sobie bardzo istotny zamysł treściowy i w pewnym sensie także metodologiczny. Jan Paweł II pragnął pójść podobną drogą jak Leon XIII, gdyż główną przyczynę zła społecznego w kończącym się xx wieku zdawał się widzieć nade wszystko w dominacji fałszywej koncepcji wolności, która w dziedzinie działalności gospodarczej, społecznej, politycznej czy nawet kulturowej nie zważa na prawdę o człowieku, jego osobową i społeczną naturę 7 .

W czasie, kiedy Jan Paweł II pisał encyklikę Centesimus annus, a więc spoglądając dokoła, był przekonany, że fałszywa wolność niemal zadomowiła się w całej cywilizacji euroatlantyckiej. Wolność jako wartość

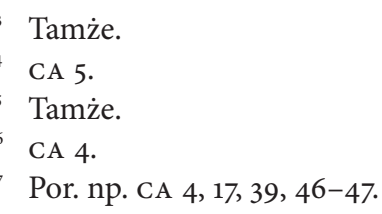


została oderwana od całokształtu życia społecznego, zaś jej ideologiczna postać zaczęła wywierać ogromny wpływ szczególnie na politykę. Wchodzący w ponowoczesność świat nie postrzega już polityki jako „roztropnej troski o dobro wspólne", ponieważ stopniowo zatraca poczucie dobra, także dobra wspólnego. Tego rodzaju mentalność, w gruncie rzeczy kryjąca w sobie błąd antropologiczny ${ }^{9}$, w niemałym stopniu przejawia się także na polu polityki społecznej.

\section{Troska o realizację „dobra socjalnego”}

Czytając encyklikę Centesimus annus, można odnieść wrażenie, że jej Autor, spoglądając w przyszłość, widzi „rzeczy nowe” właśnie w kluczu ogromnych przemian, którym znaczenie usiłują nadać groźne ideologie skażone błędem antropologicznym. W tym miejscu rodzi się pytanie o to, jak w tej perspektywie jawi się polityka społeczna, jej istotne zadania i stojące przed nią rzeczywiste wyzwania w ramach troski o realizację "dobra socjalnego".

Cóż to jest „dobro socjalne”? Wydaje się, iż o takiej kategorii można mówić w sensie analogicznym do dobra wspólnego, które jest, a przynajmniej być powinno, centralnym motywem polityki jako takiej. W tym znaczeniu na dobro socjalne składają się podstawowe cele polityki społecznej, które ją definiują. Etyczny wymiar tych celów jest głównym przedmiotem nauczania społecznego Kościoła, w szczególności encyklik społecznych papieży. Tego rodzaju wymiar kryje w swoim przesłaniu także Centesimus annus. Analizując ją w aspekcie spojrzenia w przyszłość, można bez trudu zauważyć, że stanowi ona niemałą inspirację dla polityki społecznej w ponowoczesnym społeczeństwie.

Dla potrzeb niniejszych rozważań nie sposób nie nawiązać, przynajmniej pokrótce, do współczesnego rozumienia polityki społecznej. Wyrasta ono oczywiście z uwarunkowań historycznych, uwzględniając aktualne potrzeby i wyzwania o charakterze daleko wykraczającym poza ramy lokalne, regionalne czy państwowe. W dobie ponowoczesności polityka społeczna postrzegana jest wszakże w kontekście globalnym.

\footnotetext{
LE 20.

9 Por. CA 13.
} 
Wydaje się, iż trzeba przyznać rację jednemu z angielskich badaczy w dziedzinie polityki społecznej i pracy socjalnej, wedle którego tego rodzaju polityka nie jest łatwa do zdefiniowania. Stąd wiele niekiedy wręcz karkołomnych prób określenia rzeczywistości, którą można by zidentyfikować jako politykę społeczną. Niemniej jednak sam Richard Titmuss, bo o nim właśnie mowa, podjął próbę syntetycznego ujęcia tego, co w polityce społecznej najistotniejsze. Kojarzy ją bowiem z systemem usług publicznych czy systemem socjalnym, który ma na celu zaspokojenie potrzeb społecznych. Politykę społeczną interesuje zarówno zakres potrzeb, jak i efektywność funkcjonowania określonych struktur czy instytucji mających na celu zaspokojenie owych potrzeb w warunkach ich niedoboru ${ }^{10}$.

Zdaniem amerykańskiego badacza Davida Gila głównym przedmiotem polityki społecznej, definiującym jej sens, jest problem dostępności zasobów zapewniających utrzymanie ludzi przy życiu, a przy tym umożliwiających poprawę jego jakości ${ }^{11}$. W tak szeroko rozumianym zakresie do polityki społecznej zalicza się niemal każdą aktywność w ramach struktur społecznych czy instytucji, która wywiera realny wpływ na jakość ludzkiego życia.

$\mathrm{Na}$ gruncie polskim ujęcia polityki społecznej mają przeważnie charakter opisowy, wskazując jednocześnie na jej najważniejsze cele. Jednym z nich jest chociażby definicja Juliana Auleytnera, wedle której polityka społeczna w rozumieniu praktycznym to działalność odpowiednich instytucji państwowych (rządowych), samorządu terytorialnego i organizacji pozarządowych celem: wyrównywania drastycznych różnic socjalnych między obywatelami, dawania im równych szans i asekurowania ich przed skutkami ryzyka socjalnego ${ }^{12}$.

Obok wspomnianego ujęcia nie bez znaczenia pozostają definicje lansowane przez innych teoretyków polityki społecznej. Warto przywołać

${ }^{10}$ R. M. Titmuss, Commitment to welfare, London 1976, s. 20; por. tenże, Social policy, London 1974, s. $29 \mathrm{nn}$.

${ }^{11}$ Zob. D. G. Gil, Unravelling social policy. Theory, analysis, and political action towards social equality, Cambridge 1973 .

${ }^{12}$ Zob. J. Auleytner, Strategia polskiej polityki społecznej, w: Strategia rozwoju Polski do roku 2020, t. 2, Komitet Prognoz „Polska 2000 Plus” przy Prezydium Pan, Warszawa 2000, s. 169; tenże, Polityka społeczna, czyli ujarzmianie chaosu socjalnego, Warszawa 2002, s. $40-41$. 
przynajmniej niektórych. Otóż Jan Rosner przez politykę społeczną rozumiał działalność państwa i organizacji społecznych w dziedzinie kształtowania warunków bytu i pracy, zmuszającą do optymalnego zaspokajania indywidualnych i społecznych potrzeb ludności. Z kolei Michał Olędzki słusznie zauważył, że polityka społeczna koncentruje się głównie na kwestii wywołania pożądanych zmian struktury społecznej, odwołując się do dorobku naukowego dyscyplin zajmujących się diagnozą i prognozą zdarzeń ${ }^{13}$.

Dziś zarówno w Polsce, jak i w krajach przynależących do kręgu cywilizacji euroatlantyckiej zdaje się dominować przekonanie o konieczności ukierunkowania polityki społecznej na ideę państwa dobrobytu (ang. welfare state $)^{14}$. Przejawem akceptacji tej idei jest między innymi usytuowanie praw społecznych w obszarze praw człowieka. Dotyczy to praw pracowniczych, prawa do minimalnego poziomu życia, prawa do ochrony zdrowia, edukacji, a nawet tożsamości kulturowej.

Jakkolwiek by było, dziś do najbardziej podstawowych przejawów polityki społecznej należy praktyczna działalność przyczyniająca się do zaspokajania pożądanych potrzeb ludzkich. Według Kazimierza Podoskiego jej przedmiotem są potrzeby związane ze sferą bytu (wyżywienie, mieszkanie, pomoc materialna w sytuacji zdarzeń losowych czy niezdolności do pracy), potrzeby sfery pozamaterialnej (ochrona zdrowia, edukacja, rekreacja, działalność kulturalna) oraz potrzeby psychospołeczne (aktywność społeczna, poczucie bezpieczeństwa socjalnego i ekonomicznego, satysfakcja $\mathrm{z}$ wykonywanej pracy) ${ }^{15}$.

Zaspokajanie owych potrzeb dokonuje się poprzez działania opiekuńcze i prognostyczno-planistyczne. Pierwszy ich rodzaj polega na wyrównywaniu określonego społecznie standardu życiowego różnych kategorii osób i grup. Pod tym względem niezbędna jest czujność, by to „wyrównywanie" nie odbywało się z góry do dołu, lecz przejawiało tendencję

${ }^{13}$ Cyt. za: M. Gębski, Miejsce polityki społecznej w nowoczesnych systemach politycznych, „Studia i Materiały. Miscellanea Oeconomicae” 18 (2014), nr 4: Gospodarka i rozwój regionalny, s. 234.

${ }^{14}$ Problemem jest jednak samo rozumienie welfare state. Pojęcie to interpretuje się w sposób zróżnicowany, a nawet tłumaczy się na inne języki w sposób niejednolity. W języku polskim mówi się np. o „państwie opiekuńczym”, „państwie społecznym” czy „państwie o orientacji społecznej".

${ }^{15}$ Por. K. Podoski, W. Turnowiecki, Polityka społeczna, Gdańsk 2003, s. 9. 
odwrotną, czyli miało charakter rozwojowy w kierunku zamożności. Z kolei działania prognostyczno-planistyczne mają być ukierunkowane na kompleksowe i perspektywiczne (długoterminowe i zróżnicowane) rozwiązania problemów rozwoju społecznego ${ }^{16}$.

W sumie politykę społeczną można rozumieć w kategoriach całokształtu działań w sferze publicznej. Albowiem w ramach działalności państwa i jego organów oraz podmiotów samorządowych i organizacji pozarządowych kształtowane są warunki pracy i życia ludności. Warunki te przynależą niejako do konstrukcji struktur społecznych, co zakłada także odpowiednią aktywność obywateli. Nie bez uzasadnionych racji można przyjąć - jak to czyni wielu autorów - że tak rozumiana polityka społeczna stwarza możliwość najbardziej efektywnego i sprawiedliwego zaspokajania potrzeb obywateli ${ }^{17}$. Jest ona przejawem uporządkowanej troski o dobro socjalne, a nawet formą czy narzędziem realizacji tego dobra.

Można ponadto zauważyć, że polityka społeczna pod względem teoretycznym jawi się jako zbiór polityk (dyscyplin) szczegółowych, zaś praktycznie - jako zbiór polityk publicznych, które jednak nie zamykają się wyłącznie w ramach tradycyjnie rozumianej polityki społecznej. Do tego rodzaju polityk publicznych należą polityki: ludnościowa (demograficzna), rodzinna, ochrony zdrowia, zatrudnieniowa i przeciwdziałania bezrobociu, zabezpieczenia społecznego i pomocy (opieki) społecznej, oświatowa i edukacyjna, prewencji i zwalczania zjawisk patologii oraz ochrony środowiska naturalnego ${ }^{18}$.

Polityka społeczna odpowiedzialna jest za kreowanie postępu cywilizacyjnego. Czyni to poprzez wybór odpowiednich celów i realizację określonych zadań, wśród których niezwykle istotną rolę pełnią także działania opiekuńcze państwa. Chodzi bowiem o zespół podejmowanych przez państwo czynności ukierunkowanych na zaspokajanie niezbędnych potrzeb życiowych tych ludzi, których z różnych względów nie stać na ich zrealizowanie ze swoich środków indywidualnych. Tego rodzaju działania dotyczą istotnych problemów społecznych, zwłaszcza: pauperyzacji,

\footnotetext{
${ }^{16}$ Por. tamże, s. 16.

${ }_{17}$ Zob. np. M. Gębski, Miejsce polityki społecznej..., s. 234.

${ }^{18}$ Por. J. Mazur, Pro familia et societate. Wybrane zagadnienia polityki społecznej, Kraków 2013, s. 25-27.
} 
niepewności społecznej, bezrobocia, bezdomności czy w ogóle trudnej sytuacji mieszkaniowej ${ }^{19}$.

Spoglądając na współczesną politykę społeczną, nie sposób nie dostrzec wciąż dokonujących się jej przeobrażeń. Coraz częściej mówi się o wielosektorowej polityce społecznej (ang. welfare pluralism), która zakłada transformację tradycyjnego państwa opiekuńczego. Zmniejszającej się roli państwa (sektora publicznego) musi jednak towarzyszyć wzrost znaczenia lokalnej polityki społecznej, opierającej się na rosnącej roli zarówno samorządu terytorialnego, jak również, a może przede wszystkim, sektora prywatnego i gospodarki społecznej, rodziny i grup nieformalnych oraz organizacji pozarządowych ${ }^{20}$.

\section{Aksjologiczny aspekt polityki społecznej państwa}

Widać jasno, że "ponowoczesne” przemiany w postrzeganiu roli i znaczenia polityki społecznej wyrażają się w tym, iż życie obywateli w coraz szerszym zakresie obejmowane jest gwarancją osłony ze strony państwa. W praktyce oznacza to, że państwo przejmuje na siebie obowiązek rozwiązywania istniejących kwestii społecznych, stanowiących źródło potencjalnych społecznych konfliktów, a w konsekwencji staje się w coraz większym stopniu odpowiedzialne za kształt rozwoju społecznego. Mając możliwość zapewnienia takich gwarancji, współczesne państwo w sposób jakby nieunikniony urasta do rangi głównego, najważniejszego podmiotu polityki społecznej ${ }^{21}$.

Rola i znaczenie państwa, realnie kreującego politykę społeczną, wypływają nade wszytko z jego zdolności do diagnozowania sprzeczności społecznych i możliwości, jakie posiada odnośnie do wpływu na przezwyciężanie owych sprzeczności. Ukierunkowanie to nadaje polityce społecznej status ogromnie ważny. Powoduje on, że wciąż poszerza się

${ }_{19}$ Por. M. Lavalette, A. Pratt, Czym jest polityka społeczna?, w: Polityka społeczna. Teorie, pojęcia, problemy, red. M. Lavalette, A. Pratt, tłum. P. Jaworski, Warszawa 2010, s. 18-22.

${ }^{20}$ Interesująca pod tym względem jest koncepcja Mirosława Grewińskiego, który problem pluralizmu i wielosektorowości w polityce społecznej ujmuje w formie „stokrotki dobrobytu”. Zob. M. Grewiński, Wielosektorowa polityka społeczna. O przeobrażeniach państwa opiekuńczego, Warszawa 2009, s. 135-141. Por. Zrozumieć wielosektorowa gospodarkę dobrobytu, red. M. Powell, tłum. S. Kamiński, Warszawa 2010.

${ }^{21}$ Por. M. Gębski, Miejsce polityki społecznej..., s. 233. 
zakres odpowiedzialności państwa za poziom bezpieczeństwa i rozwoju społecznego oraz za minimalizowanie społecznych zagrożeń dla systemu ekonomicznego i politycznego ${ }^{22}$.

Jednak polityka społeczna każdego państwa z natury rzeczy opiera się na pewnych założeniach o charakterze doktrynalnym, które z kolei kryją w sobie bardziej lub mniej klarowne nadrzędne wartości. Jeśli polityka definiuje swoje cele i sposoby ich realizacji, to nie inaczej, jak właśnie w oparciu o wartości w znaczeniu doktrynalnym. Odnośnie do spraw gospodarczych taką wartością definiującą strategie polityki społecznej jest wolność rynku czy zasada gospodarki wolnorynkowej, oczywiście $\mathrm{w}$ różnych swoich odmianach. Wartość ta jest powszechnie przyjmowana przynajmniej w krajach wysoko rozwiniętych. Ale nie jest to wartość „autonomiczna”, gdyż musi ona współistnieć z innymi wartościami, głównie społeczno-moralnymi. Do tych ostatnich należy przede wszystkim dobro wspólne, będące dla polityki jako takiej wartością centralną. Wartości niezbędne dla polityki to także prawda o naturze społecznej człowieka, w szczególności o naturze życia społecznego, gospodarczego i politycznego. Ponadto polityka zakłada respekt wobec takich wartości, jak sprawiedliwość, solidarność, pokój społeczny, odpowiedzialność, równość wobec prawa, miłość społeczna. Niezbędne są także religia czy patriotyzm, nie wspominając już o wartościach mających ściśle osobowy charakter, jak oszczędność, zaradność itp. Są to wartości podstawowe, ogólnoludzkie, które na gruncie praktycznej polityki społecznej przybierają postać bardziej szczegółową, jawiąc się przeważnie jako wartości pożądane. Należą do nich: socjalne i wolnościowe prawa człowieka, dobrobyt, równość szans na awans społeczny, poczucie bezpieczeństwa socjalnego, szczęście osobiste i rodzinne czy chociażby emancypacja grup wykluczonych lub zagrożonych wykluczeniem ${ }^{23}$.

Dla szeroko rozumianej polityki społecznej państwa problemem podstawowym, niejako wyjściowym, są wspomniane wartości, ich interpretacja i uzasadnienie. Nie można ich wyprowadzać wyłącznie w oparciu o wewnętrzną analizę samej polityki. Trzeba wyjść poza jej obszar, stawiając pytanie o to, kim jest człowiek, jaki jest sens ludzkiego życia, w czym

\footnotetext{
${ }^{22}$ Tamże.

${ }^{23}$ Por. J. Mazur, Pro familia et societate..., s. 94-97.
} 
wyraża się stosunek człowieka do świata i społeczeństwa, jak przedstawia się sprawa powołania i przeznaczenia człowieka.

Odpowiedzi na te pytania dostarczają nauki o człowieku, filozofia, jak również teologia czy w ogóle religia, zwłaszcza religia katolicka przeżywana jako żywa relacja człowieka z Bogiem. Nic zatem dziwnego, że w tego rodzaju posługę względem polityki społecznej także wpisuje się nauczanie społeczne Jana Pawła II. Jego encyklika Centesimus annus stara się dać jasne wskazania aksjologiczne i etyczne odnośnie do tego, co powinno być uznane za cenne, pożądane, wartościowe w polityce społecznej właśnie z uwagi na dobro człowieka w znaczeniu egzystencjalnym i nadprzyrodzonym.

\section{Optyka „znaków czasu”}

W niniejszych rozważaniach chodzi głównie o uchwycenie tych elementów nauczania, które stanowią spojrzenie w przyszłość. Przed 25 laty stanowiły one rodzaj inspiracji dla tych, którzy odpowiedzialni byli za wybór kierunków rozwoju ludzkości. Jednakże encyklika nie tylko ma charakter inspirujący, ale także kryje w sobie konkretne wskazania i ostrzeżenia odnośnie do polityki i gospodarki, aby w ten sposób pomóc ludzkości wejść w to, co współcześni intelektualiści niemal powszechnie określają mianem ponowoczesności. Dziś, gdy treści encykliki można bez trudu skonfrontować z ponowoczesną rzeczywistością, odsłania się profetyczny charakter tego dokumentu, zaś jego diagnozy i prognozy, przekraczając sferę czysto religijną, wychodzą naprzeciw także aktualnym, ponowoczesnym wyzwaniom i zadaniom polityki społecznej. Niektóre z owych papieskich przemyśleń można śmiało zaliczyć to „znaków czasu” ${ }^{24}$, których wymowa jeszcze bardziej ujawnia się i cywilizacyjnie konkretyzuje właśnie w ramach ponowoczesności.

\section{I. Realizm nowych form własności}

Warto dokonać przeglądu owych znaków, konfrontując je z aktualnymi wyzwaniami i zadaniami polityki społecznej. Otóż w tym kontekście

\footnotetext{
${ }^{24}$ Zob. tenże, Znaki czasu, hasło w: Wielka encyklopedia nauczania Jana Pawła II, Radom 2014, s. 1175-1179.
} 
na pierwszy plan zdaje się wysuwać problem własności. Papież, przywołując tradycyjną naukę Kościoła o własności prywatnej, mającej z natury swej charakter społeczny, odczytał ją niejako na nowo w odniesieniu do pytania o „pochodzenie dóbr, które utrzymują człowieka przy życiu, zaspokajają jego potrzeby i są przedmiotem jego praw"25. Autor czyni to z uwagi na realne próby kwestionowania prawa własności prywatnej przez ideologie lewicowe, a szczególnie socjalistyczne, promujące zasadę własności wspólnej, kolektywnej, państwowej.

Centesimus annus przypomina, że „wszystko, co dobre” stanowi akt stwórczy i zarazem dar Boga. Albowiem Bóg, stwarzając ziemię, dał ją całemu rodzajowi ludzkiemu, aby utrzymywała wszystkich jego członków, nie wyłączając ani nie wyróżniając nikogo. Jednakże ziemia wydaje niezbędne owoce dla człowieka dopiero wówczas, gdy spotka się z właściwą jego odpowiedzią, którą jest praca. Dzięki pracy, bazując na swej inteligencji i wolności, człowiek niejako nabywa część ziemi, „przywłaszcza ją sobie, by panować nad nią i uczynić z niej swe mieszkanie"26. Praca zatem leży u genezy własności indywidualnej, co w konsekwencji oznacza, że do tego rodzaju własności powinni mieć dostęp wszyscy, o ile dzięki pracy wytwarzają dobra ważne dla ludzkiej egzystencji. Własność indywidualna (prywatna) jako zasada w niczym jednak nie unieważnia prawdy o powszechnym przeznaczeniu dóbr ziemi.

W tym tradycyjnym postrzeganiu własności - własności uwarunkowanej pracą - Jan Paweł II zwracał uwagę na kontekst cywilizacyjny. Zauważył w pewnym sensie „rzecz nową”, mianowicie to, że pod koniec xx wieku wzrasta rola pracy jako czynnika wytwarzającego dobra materialne i niematerialne, a ponadto praca jednego człowieka splata się w sposób naturalny z pracą innych ludzi. Innymi słowy, pracować to znaczy „robić coś dla kogoś”, pracować z innymi i dla innych. Takie ukierunkowanie pracy zakłada pogłębioną znajomość ludzkich potrzeb, poznanie możliwości wytwórczych i zdolność wytwarzania dóbr, które te potrzeby zaspokajają ${ }^{27}$.

W tym kontekście encyklika wskazuje na swego rodzaju „znak czasu", jakim jest znaczenie szczególnego rodzaju formy własności. Chodzi

\footnotetext{
${ }^{25}$ CA 30.

${ }^{26}$ Por. CA 31.

27 Tamże.
} 
mianowicie o własność wiedzy, techniki i umiejętności. Ten typ własności oparty jest na uznaniu roli zdyscyplinowanej i kreatywnej pracy ludzkiej, w której determinantę stanowi zdolność do inicjatywy i przedsiębiorczości. Wydaje się, że ta diagnoza, będąca zarazem prognozą, okazała się nad wyraz trafna. Rozwój ekonomiczny poszedł właśnie w tym kierunku. Decydującym czynnikiem produkcji nie jest już ziemia czy kapitał, rozumiany jako element narzędziowy, ale sam człowiek ze swoją wiedzą, swoimi zdolnościami do uczestnictwa w solidarnej organizacji pracy, umiejętnościami wyczuwania i zaspokajania potrzeb innych ludzi.

Chociaż przywołany znak kryje w sobie aspekt pozytywny, wszak współczesny duch ekonomii deklaruje poszanowanie prawa do wolności oraz zakłada obowiązek odpowiedzialnego z niej korzystania, to jednak nie jest on wolny od aspektów negatywnych. Problem postrzegania nowych form własności i korzystania z nich wciąż narasta i ujawnia towarzyszące mu niebezpieczeństwa czy zagrożenia. Okazuje się, że może zagrażać samemu człowiekowi pracy, gdyż większość ludzi nie jest zdolna do zdobycia podstawowej wiedzy, która pozwoliłaby im osiągnąć zdolność tworzenia i rozwijania swoich możliwości i tym samym cieszyć się rozwojem swojego osobowego potencjału. Skutkiem tego cały rozwój dokonuje się „ponad ich głowami, o ile wprost nie ogranicza już i tak zawężonej przestrzeni ich działalności gospodarczej, z której żyją". Sprawia to, że ludzie ci w znacznej mierze pozostają na marginesie, są wykorzenieni kulturowo i zagrożeni tymczasowością, a nierzadko „nie przyznaje się im żadnej godności czy realnych ludzkich możliwości”, usiłując ich wykluczyć, względnie zmarginalizować, przez lansowaną $\mathrm{w}$ różnych formach kontrolę demograficzną, sprzeczną z ludzką godnością ${ }^{28}$. Dlatego ogromne rzesze ludzi, a może nawet i większość ludzkości, żyją w niepewności, w warunkach zmuszających do nieustannego zabiegania o zaspokojenie podstawowych potrzeb życiowych, a nawet w sytuacji walki o przetrwanie ${ }^{29}$.

\subsection{Rola i znaczenie wolnego rynku}

Innym znakiem czasu, uwzględnionym w encyklice Centesimus annus, którego analiza okazała się trafnym spojrzeniem w przyszłość, jest rola

\footnotetext{
${ }^{28}$ CA 33.

${ }^{29}$ CA 33.
} 
i znaczenie wolnego rynku. Zdaniem Jana Pawła II wolny rynek niemal powszechnie uchodzi za najbardziej skuteczne narzędzie wykorzystania zasobów i zaspokajania potrzeb. Papież zaakcentował jednak prawdę, że skuteczność wolnego rynku dotyczy tylko takich potrzeb, które dysponują siłą nabywczą, a więc za których zaspokojenie można zapłacić. Podobnie rzecz wygląda z zasobami. Wolny rynek sprzyja wykorzystaniu jedynie tych zasobów, które mogą uzyskać odpowiednią cenę, czyli nadają się do sprzedania ${ }^{30}$. Tymczasem istnieje cały szereg potrzeb i zasobów, których nie można zaspokoić czy wykorzystać w ramach wolnego rynku, gdyż one nie mają do niego dostępu. W tym miejscu problemem są nade wszytko - jak słusznie zauważył Jan Paweł II - podstawowe potrzeby ludzkie. Przypomniał on wszystkim ludziom odpowiedzialnym za dobro wspólne ludzkości, że w imię sprawiedliwości i prawdy nie wolno dopuścić do tego, by potrzeby te były niezaspokojone ${ }^{31}$.

Propozycja papieża jest doprawdy spojrzeniem w ponowoczesną przyszłość, w której widział on konieczność przezwyciężenia mentalności wolnorynkowej. Apelował o takie rozwiązania, które gwarantowałyby zaspokojenie podstawowych potrzeb całego społeczeństwa. Jego zdaniem ustrój gospodarczy oparty na wolnym rynku nie może sprowadzać się do systemu zabezpieczającego „absolutną dominację kapitału oraz własności narzędzi produkcji i ziemi nad podmiotowością i wolnością pracy człowieka" ${ }^{2}$.

Aby w gospodarce wolnorynkowej została przywrócona należyta ranga podmiotowości i wolności pracy ludzkiej, Jan Paweł i zaproponował odpowiedni model społeczeństwa. Jest to społeczeństwo, w którym istnieją: wolność pracy, przedsiębiorczość i uczestnictwo ${ }^{33}$. Wydaje się, iż kreowanie takiego społeczeństwa jest niezbędnym wymogiem właściwego, a więc integralnego i solidarnego, rozwoju w ponowoczesnym świecie. Jednym z przejawów realizacji tego modelu jest idea społeczeństwa obywatelskiego, dla której dziś istnieje niemal powszechne zrozumienie i akceptacja. Jakkolwiek by było, trzeba przyznać, że idea społeczeństwa opartego na wolności pracy, przedsiębiorczości i uczestnictwie jest wciąż

\footnotetext{
${ }^{30}$ CA 34.

${ }^{31}$ Por. tamże.

32 CA 35.

33 Tamże.
} 
aktualna i stanowi przejrzystą odpowiedź na znak czasu, jakim jest rola i znaczenie wolnego rynku.

\subsection{Konsumizm}

Kolejnym znakiem czasu wydaje się zjawisko konsumizmu, które również przywoływane jest w Centesimus annus. Otóż konsumizm - zdaniem Jana Pawła II - wpisuje się w całościową wizję życia, wytworzoną przez określone decyzje związane z produkcją i konsumpcją ${ }^{34}$. Wedle papieża, określając nowe potrzeby i nowe sposoby ich zaspokajania, należy koniecznie kierować się integralną wizją człowieka.

Dlatego spoglądając w przyszłość, autor Centesimus annus przestrzegał przed tendencją ujawniającą się w prymacie wymiaru materialnego i instynktownego wobec wymiaru wewnętrznego i duchowego człowieka. W encyklice widnieje wszakże zdanie: „odwoływanie się bezpośrednio do instynktów [człowieka] i ignorowanie na różne sposoby jego wolnej i świadomej natury osobowej może prowadzić do wytworzenia nawyków konsumpcyjnych i stylów życia obiektywnie niegodziwych lub szkodliwych dla fizycznego i duchowego zdrowia"35.

Słusznie papież zauważył, że w systemie gospodarczym, bez względu na to, jaki by on nie był, nie ma kryteriów, które pozwalałyby na odróżnienie "nowych i doskonalszych form zaspokajania potrzeb ludzkich od potrzeb sztucznie stwarzanych, przeszkadzających kształtowaniu się dojrzałej osobowości" ${ }^{36}$. Problem polega na tym, że tego rodzaju kryteria istnieją poza ekonomią. Można je odnaleźć w wieloaspektowej czy wielowymiarowej analizie natury ludzkiej. Analiza ta, prowadzona na gruncie personalizmu chrześcijańskiego, prowadzi do wyboru czy tworzenia takich stylów życia, w których być dominuje nad mieć, zaś „szukanie prawdy, piękna i dobra oraz wspólnota ludzi dążących do wspólnego rozwoju" stanowią elementy decydujące o „wyborze jakości konsumpcji, oszczędności i inwestycji”" ${ }^{37}$.

\footnotetext{
34 Por. CA 36.

35 Tamże.

36 Tamże.

37 Tamże.
} 
Ponowoczesność naznaczona takimi kategoriami, jak: społeczeństwo informacyjne, społeczeństwo wiedzy, społeczeństwo ryzyka, społeczeństwo sieciowe czy społeczeństwo globalne zorganizowane na wzór globalnej wioski - szczególnie zagrożona jest chaosem występującym w dziedzinie ludzkich potrzeb. Jeśli zakwestionuje się autentyczną antropologię, analizującą rzetelnie ludzką naturę, to nie sposób odnaleźć właściwych kryteriów powalających na odróżnienie innowacyjnych form zaspokajania potrzeb od szkodliwych potrzeb kreowanych sztucznie. Potrzeby sztucznie wytwarzane, najczęściej za pośrednictwem cyberprzestrzeni, z reguły służą wyłącznie biznesowi, pozostając poza zasięgiem autentycznego szukania prawdy, piękna i dobra. Wtedy jakość konsumpcji, oszczędności czy inwestycji nie integruje ludzi zainteresowanych wspólnym rozwojem. W praktyce ignoruje się fakt, że wybory w zakresie konsumpcji, oszczędności i inwestycji zawsze są wyborami o charakterze moralnym i kulturowym.

Tego rodzaju problemy nic nie tracą dziś na swej aktualności. W dobie ponowoczesności narastają, i to w skali globalnej. Wciąż bardzo wiele potrzeb podstawowych pozostaje niezaspokojonych. Dzieje się tak zwłaszcza w Trzecim i Czwartym Świecie ${ }^{38}$, podczas gdy w krajach wysokorozwiniętych zaspokajane są w nadmiarze potrzeby wytworzone sztucznie. Stawia to pod znakiem zapytania, a przynajmniej czyni moralnie wątpliwą jakość konsumpcji, oszczędności i inwestycji. Widać zatem, że zjawisko konsumizmu urastające do rangi znaku czasu stanowi niewątpliwe wyzwanie dla polityki społecznej w ponowoczesnym społeczeństwie. Czyni ją odpowiedzialną za kształtowanie jakości konsumpcji, co z kolei wymaga przyjęcia odpowiednich strategii rozwoju z wszystkimi jego parametrami. Papież szczególnie podkreślił czynnik moralny, wskazując na potrzebę: po pierwsze, odpowiedniej formacji konsumentów do odpowiedzialnego korzystania $\mathrm{z}$ prawa wyboru w zakresie dóbr i usług; po drugie, kształtowania u producentów, a także u specjalistów w dziedzinie społecznego przekazu głębokiego poczucia odpowiedzialności; i po trzecie, interwencji władz publicznych odnośnie

\footnotetext{
${ }^{38}$ Kategorie „Trzeci Świat” i „Czwarty Świat” występują w encyklice w kontekście apelu o równoprawny dostęp do rynku międzynarodowego i lepsze wykorzystanie potencjału ludzkiego. Zob. cA 33.
} 
do twórczych możliwości wolnej gospodarki ${ }^{39}$. Chodzi przykładowo o przeciwdziałanie konsumpcji sztucznej, szkodliwej dla zdrowia i godności człowieka, która z reguły stanowi wskaźnik poważnych zaburzeń w funkcjonowaniu systemu społecznego (socjalnego). Do tego rodzaju konsumpcji niewątpliwie należą narkomania, alkoholizm czy ostatnio w dobie ponowoczesności - siecioholizm.

\subsection{Dominacja ideału demokratycznego}

Na koniec trzeba zauważyć jeszcze jeden znak czasu, jakim jest „dominacja ideału demokratycznego" ${ }^{40}$. Można by oczywiście mówić także o innych znakach, takich chociażby jak problem „ekologii ludzkiej”, ale dla całości rozważań problem demokracji jawi się jako rodzaj kultury wyznaczającej ogólne funkcjonowanie polityki społecznej. W kluczu tej kultury możliwe są do odczytania wszystkie pozostałe znaki czasu.

Zagadnienie demokracji encyklika ujmuje w kontekście totalitaryzmu, który funkcjonował w świecie przez wiele dziesięcioleci w formie marksistowsko-leninowskiej. Analiza papieska tego rodzaju rzeczywistości ma charakter przede wszystkim etyczny. Usiłuje bowiem odczytać totalitaryzm w kluczu wartości, jaką jest posłuszeństwo obiektywnej prawdzie. Oto słowa papieża: „Totalitaryzm rodzi się z negacji obiektywnej prawdy: jeżeli nie istnieje prawda transcendentna, przez posłuszeństwo której człowiek zdobywa swą pełną tożsamość, to nie istnieje też żadna pewna zasada, gwarantująca sprawiedliwe stosunki pomiędzy ludźmi. Istotnie, ich klasowe, grupowe i narodowe korzyści nieuchronnie przeciwstawiają jednych drugim. Jeśli się nie uznaje prawdy transcendentnej, triumfuje siła władzy i każdy dąży do maksymalnego wykorzystania dostępnych mu środków, do narzucenia własnej korzyści czy własnych poglądów, nie bacząc na prawa innych" ${ }^{41}$.

Zdaniem autora encykliki Centesimus annus państwo totalitarne dąży do zawładnięcia narodem, społeczeństwem, rodziną, wspólnotami religijnymi, organizacjami społecznymi i poszczególnymi osobami. W tej sytuacji należy - jak zaznaczył papież - docenić demokrację jako system

\footnotetext{
39 CA 36.

${ }^{40}$ CA 47.

${ }^{41}$ CA 44.
} 
zapewniający udział obywateli w decyzjach politycznych. Jednak autentyczna demokracja możliwa jest tylko w państwie prawa, którego „filozofia" przyjmuje poprawną koncepcję osoby ludzkiej. Niestety, problem polega na tym, że na początku lat 9o. xx wieku ową filozofią - wedle zdania Jana Pawła II - był agnostycyzm i sceptyczny relatywizm ${ }^{42}$. Jak nietrudno zauważyć, pod tym względem sytuacja niewiele się zmieniła. Dziś agnostycyzm i sceptyczny relatywizm zdają się jeszcze bardziej dominować nad przekonaniem o istnieniu ostatecznej prawdy, którą można poznać, za którą trzeba zdecydowanie pójść i której warto bronić.

Okazuje się, że współczesna filozofia demokracji jest coraz bardziej konsekwentna w negowaniu istnienia obiektywnej prawdy, zaś tych, którzy taką prawdę uznają, nie uważa za godnych zaufania. Dlatego Jan Paweł II $\mathrm{z}$ naciskiem wyraził swoje zdanie w formie przestrogi: „W sytuacji, w której nie istnieje żadna ostateczna prawda, będąca przewodnikiem dla działalności politycznej i nadająca jej kierunek, łatwo o instrumentalizację idei i przekonań dla celów, jakie stawia sobie władza. Historia uczy, że demokracja bez wartości łatwo się przemienia w jawny lub zakamuflowany totalitaryzm"43.

Nie ulega wątpliwości, że współczesna polityka społeczna uwikłana jest właśnie w tę niebezpieczną filozofię, negującą obiektywną (naturalną) prawdę o człowieku. Polityka ta opiera się w zasadzie tylko na prawdzie „demokratycznej”, a więc takiej, którą określa większość danego układu politycznego. W praktyce uwarunkowana jest ona zmienną równowagą polityczną. Czyż nie dlatego współczesna demokracja przeradza się w zakamuflowany totalitaryzm? Jego przejawem zdaje się być dyktatura mniejszości, które lansują swoje "prawdy”, niemające nic wspólnego z autentyczną, obiektywną prawdą o człowieku. Jest to szczególnie widoczne w obszarze polityki społecznej. Prawa socjalne dla gejów czy lesbijek jako odrębnych kategorii ludzi, ochrona socjalna dla związków partnerskich różnych rodzajów, polityka demograficzna zakładająca zgodę prawną na aborcję, antykoncepcję czy eutanazję, brak wystarczającej troski o zdrowie publiczne lub fatalna $\mathrm{w}$ wielu krajach polityka zdrowotna - oto konkretne konsekwencje braku respektu wobec obiektywnej prawdy o człowieku, jego godności, powołaniu i przeznaczeniu.

\footnotetext{
${ }^{42}$ Zob. CA 46.

43 Tamże.
} 


\section{Propozycja dla prekaryzmu}

Trafność spojrzenia w przyszłość, jakiego dokonał w encyklice Centesimus annus Jan Paweł II, można dziś, jak się wydaje, zweryfikować na przykładzie analizy zjawiska prekaryzmu (prekariatu). O ile Rerum novarum było wielkim apelem o przezwyciężenie kwestii proletariackiej, zaś Centesimus annus wołaniem o zwrócenie uwagi na „wielorakie współczesne wymiary kwestii społecznej" ${ }^{44}$, o tyle dziś, w dobie ponowoczesności, trzeba by podkreślić wymiar bodaj najbardziej istotny tej kwestii, mianowicie właśnie problem prekaryzmu. Czy aktualnie urasta on do rangi kwestii prekariackiej? Wydaje się, iż przemiany w świecie prowadzą w tym właśnie kierunku.

Jeśli chodzi o termin „prekariat”, to jego obecność w dyskursie społecznym i politycznym zaproponował Guy Standing, ekonomista, profesor University of Bath (Anglia) ${ }^{45}$. Samo słowo jest neologizmem powstałym z połączenia dwóch słów: precarious (ang. niepewny) ze słowem „proletariat". W ujęciu Standinga prekariat jest kategorią społeczną dla okresu późnego kapitalizmu czy właśnie ponowoczesności, zaś prekariusze to ci wszyscy, którzy zatrudnieni są na podstawie elastycznych, egzystencjalnie niepewnych form zatrudnienia. Innymi słowy, do tej grupy należą ludzie o niestabilnych dochodach i wciąż zagrożonej pozycji na rynku pracy, nieustannie balansujący na granicy finansowej katastrofy. Ponadto stosunki pracy nie zapewniają im tożsamości zawodowej i dostępu do gwarantowanych świadczeń socjalnych, co sprawia, iż nie czują się bezpieczni pod względem egzystencjalnym. Dlatego ci wszyscy, którzy tworzą szeregi prekariatu, „dryfują pozbawieni celu, z przyczajonym gniewem, zdolni skręcić politycznie w stronę skrajnej prawicy lub skrajnej lewicy, wzmacniając populistyczną demagogię, która gra na ich obawach i fobiach" 46 .

W kontekście pytania o kwestię proletariacką warto rozważyć, kogo dziś w Polsce można by uznać za prekariusza. Wydaje się, iż wiele racji

${ }^{44}$ CA 10.

45 Zob. G. Standing, Prekariat. Nowa niebezpieczna klasa, tłum. K. Czarnecki, P. Kaczmarski, M. Karolak, red. nauk. M. Szlinder, Warszawa 2014.

${ }^{46}$ Cyt.za:tamże, s.5, http://www.praktykateoretyczna.pl/prekariat/o1_Prekariat_Rozdz.1.pdf (11.02.2016). 
mają ci, którzy do tej grupy zaliczają niemal wszystkich, poza beneficjentami transformacji ustrojowej będącej konsekwencją porozumień okrągłostołowych. Zatem do prekariatu należą pracujący studenci, robotnicy, sklepowi sprzedawcy, drobni przedsiębiorcy, pracownicy korporacji, a także rolnicy (właściciele nie tylko drobnych gospodarstw). W publicznym dyskursie na ten temat za prekariusza na ogół uważa się człowieka relatywnie młodego, między 20 a 35 rokiem życia, bez etatu, zatrudnionego na „umowie śmieciowej”, ze stosunkowo niską pensją i brakiem świadczeń socjalnych ${ }^{47}$.

W tej sytuacji ciśnie się na usta pytanie o to, na ile propozycje etyczne zawarte w Centesimus annus mogą przyczynić się do przełamania owej kwestii, która jawi się jako prekariacka. Nietrudno zauważyć, że na gruncie polityki społecznej (teoretycznej) można ją zinterpretować czy scharakteryzować przy pomocy takich czynników, jak asymetria, dolegliwość, niezgodność, roszczenie, sprzeczność, zagrożenie i zawodność ${ }^{48}$. Jakże nie przyznać racji Janowi Pawłowi II, który tego rodzaju problemy społeczne starał się rozważać i oceniać w kluczu ludzkiej pracy, zagrożonej błędem antropologicznym? ${ }^{49}$ Szczególnej aktualności nabiera dziś jego głos akcentujący determinującą rolę zdyscyplinowanej i kreatywnej pracy ludzkiej, zwłaszcza tej jej istotnej części, jaką jest zdolność do inicjatywy i przedsiębiorczości ${ }^{50}$.

Jednakże zgłaszając tę propozycję, autor sytuuje ją w perspektywie etyki chrześcijańskiej. Encyklika wyraża przekonanie, że „nie ma prawdziwego rozwiązania «kwestii społecznej» poza Ewangelią", zaś „rzeczy nowe” mogą w Ewangelii „odnaleźć swoją przestrzeń prawdy i odpowiedni fundament moralny" "51. Czyż istnieje szansa na przezwyciężenie kwestii prekariackiej poza Ewangelią, a więc poza wartościami i zasadami moralnymi, które głosi chrześcijaństwo, w szczególności katolicka nauka społeczna?

${ }^{47}$ Por. Ł. Pawłowski, Czy w Polsce rzeczywiście jest prekariat?, http://kulturaliberalna. pl/2015/o6/30/polska-prekariat-definicja-standing-tyrowicz (12.02.2016); M. Beylin, Prekariat. Jakoś to znosimy. Jeszcze, http://wyborcza.pl/magazyn/1,145324,18170340 (12.02.2016).

${ }_{48}$ Zob. J. Mazur, Pro familia et societate..., s. 40-43.

${ }^{49}$ Por. CA 13; LE 3.

${ }^{50} \mathrm{CA} 32$.

${ }^{51}$ CA 5 . 
Papież Jan Paweł II w zakończeniu Centesimus annus napisał, że Kościół w swoim nauczaniu społecznym ciągle podejmuje zmaganie $\mathrm{z}$ sytuacją, którą niegdyś Leon xiII, autor Rerum novarum, określił jako „jarzmo prawie niewolnicze" ${ }^{2}$. Jarzmo to nadal dźwiga wiele grup społecznych, kategorii zawodowych, ludów w krajach dopiero wkraczających na drogę rozwoju, a także mieszkańców tak zwanego Czwartego Świata.

Wobec wciąż pojawiających się „rzeczy nowych” i nowych wyzwań nie słabnie rola i znaczenie polityki społecznej. Do niej bowiem w pierwszym rzędzie należy troska o to, by uwolnić ludzi właśnie od „niewolniczego jarzma" i w konsekwencji zintegrować z całym społeczeństwem, by w pełni, na miarę swej godności, uczestniczyli w dobru wspólnym. Nadal wszakże dźwigają to "jarzmo" ofiary rozmaitych kryzysów ekonomicznych, konfliktów wojennych, gospodarczych dominacji czy politycznych dyktatur. Chodzi o to, aby w praktyce życia społecznego, politycznego i gospodarczego uszanować prawdę o ich ludzkiej godności, co w perspektywie religijnej, chrześcijańskiej oznacza proces przezwyciężania skutków grzechu pierworodnego. Oby dla tego procesu, niekoniecznie postrzeganego religijnie, nie zabrakło zrozumienia także wśród polityków społecznych!

\section{Bibliografia}

Auleytner J., Polityka społeczna, czyli ujarzmianie chaosu socjalnego, Wydawnictwo WSP TWP, Warszawa 2002.

Auleytner J., Strategia polskiej polityki społecznej, w: Strategia rozwoju Polski do roku 2020, t. 2, Komitet Prognoz „Polska 2000 Plus” przy Prezydium Pan, Dom Wydawniczy „Elipsa”, Warszawa 2000.

Beylin M., Prekariat. Jakoś to znosimy. Jeszcze, http://wyborcza.pl/magazyn/1,145324,18170340 (12.02.2016).

Gębski M., Miejsce polityki społecznej w nowoczesnych systemach politycznych, „Studia i Materiały. Miscellanea Oeconomicae” 18 (2014), nr 4: Gospodarka i rozwój regionalny, s. 233-245.

${ }^{52}$ Zob. CA 61. 
Gil D. G., Unravelling social policy. Theory, analysis, and political action towards social equality, Schenkman Publishing Company, Cambridge 1973.

Grewiński M., Wielosektorowa polityka społeczna. O przeobrażeniach państwa opiekuńczego, Wydawnictwo wsP TwP, Warszawa 2009.

Jan Paweł II, Encyklika Centesimus annus, przedruk: Libreria Editrice Vaticana, Włocławek 1991.

Jan Paweł II, Encyklika Laborem exercens, Wydawnictwo Ośrodka Dokumentacji i Studiów Społecznych, Warszawa 1982.

Lavalette M., Pratt A., Czym jest polityka społeczna?, w: Polityki społeczna. Teorie, pojęcia, problemy, red. M. Lavalette, A. Pratt, tłum. P. Jaworski, Wydawnictwo Difin, Warszawa 2010, s. 18-22.

Mazur J., Pro familia et societate. Wybrane zagadnienia polityki społecznej, Wydawnictwo Naukowe UPJPII, Kraków 2013.

Mazur J., Znaki czasu, hasło w: Wielka encyklopedia nauczania Jana Pawła II, Polskie Wydawnictwo Encyklopedyczne „Polwen”, Radom 2014, s. 1175-1179.

Pawłowski Ł., Czy w Polsce rzeczywiście jest prekariat?, http://kulturaliberalna. $\mathrm{pl} / 2015 / 06 / 30 /$ polska-prekariat-definicja-standing-tyrowicz (12.02.2016).

Podoski K., Turnowiecki W., Polityka społeczna, Wydawnictwo Uniwersytetu Gdańskiego, Gdańsk 2003.

Polityka społeczna. Teorie, pojęcia, problemy, red. M. Lavalette, A. Pratt, thum. P. Jaworski, Wydawnictwo Difin, Warszawa 2010.

Standing G., Prekariat. Nowa niebezpieczna klasa, tłum. K. Czarnecki, P. Kaczmarski, M. Karolak, red. nauk. M. Szlinder, Wydawnictwo Naukowe PWN, Warszawa 2014.

Titmuss R. M., Commitment to welfare, Allen and Unwin, London 1976.

Titmuss R. M., Social policy, Allen and Unwin, London 1974.

Zrozumieć wielosektorowa gospodarkę dobrobytu, red. M. Powell, tłum. S. Kamiński, Wydawnictwo wsP TwP, Warszawa 2010.

\section{Abstrakt}

Tekst jest próbą odczytania encykliki społecznej Centesimus annus Jana Pawła II w perspektywie 25 lat, które upłynęły od czasu jej ogłoszenia. Zastosowano metodę zaproponowaną przez autora tego dokumentu, którą charakteryzują trzy aspekty: spojrzenie wstecz, spojrzenie dokoła i spojrzenie w przyszłość. W ramach przeprowadzonej analizy uwzględniono następujące tematy: Specyfika relektury „Rerum novarum” (dokonanej przez autora Centesimus annus); 
Troska o realizacje „dobra socjalnego” (rzut oka na najważniejsze wyzwania i zadania współczesnej polityki społecznej); Aksjologiczny aspekt polityki społecznej państwa; Optyka „znaków czasu” (zidentyfikowanych w Centesimus annus, do odczytywania których zachęcał niegdyś Sobór Watykański II). Tymi znakami są: nowe formy własności, rola i znaczenie wolnego rynku, konsumizm, dominacja ideału demokratycznego. Ważnym tematem poruszonym w końcowej części artykułu jest problem, na ile przesłanie Centesimus annus może być propozycją dla przezwyciężenia zjawiska współczesnego prekaryzmu.

Wobec wciąż pojawiających się „rzeczy nowych” i nowych wyzwań cywilizacyjnych nie słabnie rola i znaczenia polityki społecznej. Do niej w pierwszym rzędzie należy troska o to, by przezwyciężyć istniejące kwestie społeczne. Inspiracją dla tego rodzaju polityki może być nauczanie społeczne Kościoła, w szczególności zaś encyklika Centesimus annus Jana Pawła II, upamiętniająca setną rocznicę encykliki Rerum novarum Leona XIII.

Inspiration from Centesimus annus for social policy in the postmodern society
Abstract
This text is an attempt to read John Paul II's social encyclical Centesimus annus from the perspective of the 25 years that have elapsed since its announcement. The method proposed by the author of the document was used, which is cha- racterized by three aspects: „looking back”, „looking around” and „looking to the future".
The analysis includes the following topics: The specifics of a rereading of „Rerum novarum" (carried out by the author of Centesimus annus); Concern for the im- plementation of the "social good" (a glance at the most important challenges and tasks of modern social policy); The axiological aspect of state social policy; The perspective of the "signs of the times" (identified in Centesimus Annus, the Second Vatican Council once encouraged a rereading of these). These signs are: the new forms of property, the role and importance of the free market, consumerism, the dominance of the democratic ideal. An important topic in the final part of the article is the problem of how the message of Centesimus annus could be put forwards as a means of overcoming the phenomenon of contemporary precarity. 
Faced with "new things" that are still emerging and the new challenges of civilization, the role and importance of social policy does not decrease. Concern about overcoming existing social issues belongs in the field of social policy first and foremost. The social teaching of the Church can be the inspiration for this kind of policy, particularly John Paul II's encyclical Centesimus annus, which commemorated the hundredth anniversary of Leo XIII's encyclical Rerum novarum. 